\title{
INFLUENCE OF THE PINEAL GLAND ON THE PHYSIOLOGY, MORPHOMETRY AND MORPHOLOGY OF PANCREATIC ISLETS IN RATS
}

\author{
LIMA, L. M. B. de, ${ }^{1}$ REIS, L. C. $\operatorname{dos}^{1}$ and LIMA, M. A. de ${ }^{2}$ \\ ${ }^{1}$ Universidade de Uberaba (Uniube) \\ 2Faculdade de Medicina do "Triângulo Mineiro" (FMTM) \\ Correspondence to: Lilian Margareth Biagioni de Lima, Rua Paschoal Salge, 39, Jardim São Bento, \\ CEP 36066-400, Uberaba, MG, Brazil, e-mail: lima@mednet.com.br \\ Received July 1, 1999 - Accepted May 15, 2000 - Distributed May 31, 2001
}

(With 7 figures)

\begin{abstract}
To investigate the influence of the pineal gland through melatonin secretion on the physiological and morphological parameters of pancreatic islets, we studied the plasma biochemistry and morphological and morphometric characteristics of the endocrine pancreas of male Wistar rats. The animals were distributed into five groups of ten rats each: NC - normal control group; NS - sham-operated group; Px (25) - pinealectomised group, studied 15-25 days after surgery; Px (70) - pinealectomised group, studied 60-70 days after surgery; ALX - alloxan monohydrate-treated group. Data are analyzed statistically by ANOVA and by the Kruskal-Wallis test. Although there was no significant difference in plasma glucose or insulin levels between the Px (25), Px (70) and NC groups, Px (25) animals showed a tendency to increased glucose and reduced insulin levels. The ALX group showed a clear elevation of plasma glucose and a reduction of plasma insulin compared to the other groups. Morphometric analysis showed a larger pancreatic islet area and a lower pancreatic islet density in the pancreas of Px (70) animals and an increase in degenerative pathological processes in the pancreatic islets of the Px (25) and ALX groups. The present results suggest that melatonin, in addition to acting on tissue sensitivity to insulin (as reported in other studies), affects the secretory action of beta cells, as demonstrated by the morphological and morphometric changes observed in pinealectomised animals.
\end{abstract}

Key words: pinealectomy, melatonin, pancreatic islet, rat, morphology.

\section{RESUMO}

A influência da glândula pineal na fisiologia, morfometria e morfologia das ilhotas pancreáticas em ratos

Com o objetivo de verificar a influência da glândula pineal, por meio da secreção de melatonina (MLT) sobre a morfologia, morfometria e fisiologia das ilhotas de Langerhans (IP), especialmente sobre a secreção e ação da insulina, foram avaliados o metabolismo, a bioquímica plasmática, a morfologia e a morfometria de segmentos de pâncreas de 50 ratos Wistar. Os animais foram distribuídos em cinco grupos de dez animais cada, sendo dois grupos controles: $\mathrm{N}$ (controle normal); $\mathrm{CF}$ (submetidos à cirurgia fictícia) e três grupos experimentais: $\mathrm{P}_{1}$ (pinealectomizados e avaliados entre 15 e 25 dias pós-cirurgia); $\mathrm{P}_{2}$ (pinealectomizados e avaliados entre 60 e 70 dias pós-cirurgia) e Alx (tratados com Aloxana). Os resultados obtidos dos grupos experimentais foram analisados estatisticamente por ANOVA e teste de Kruskal-Wallis e comparados com os obtidos do grupo N. Embora não houvesse diferença significativa nos níveis plasmáticos de glicose ou insulina entre os grupos $\mathrm{P}_{1}, \mathrm{P}_{2}$ e N, os animais do grupo $\mathrm{P}_{1}$ mostraram tendência de aumento da glicose e níveis reduzidos de insulina. O grupo Alx mostrou elevação da glicemia e redução da insulinemia em relação aos demais grupos. A análise morfométrica revelou maior área e menor densidade das IP nos segmentos dos pâncreas do grupo $\mathrm{P}_{2}$. Em relação à análise morfológica, observou-se maior intensidade dos processos patológicos degenerativos 
nas IP dos grupos $\mathrm{P}_{1}$ e Alx. Estes resultados indicam que a MLT, além de exercer ação na sensibilidade periférica à insulina, parece ainda ter algum efeito na atividade secretora das células $\beta$ das IP, tendo em vista as alterações morfológicas e morfométricas observadas nos animais pinealectomizados.

Palavras-chave: pinealectomia, melatonina, ilhotas pancreáticas, rato, fisiologia, morfologia, morfometria.

\section{INTRODUCTION}

The pineal body is an endocrine gland that acts by synchronizing endogenous rhythms with environmental ones, especially the light-dark cycle, through its main secretion product, the melatonin hormone (N-acetyl-5-metoxytryptamine - MLT), whose production exhibits a diurnal rhythm with higher plasma levels during the dark period and lower levels during the light period (Reiter, 1986; Reiter \& Robinson, 1996). Several other functions have been attributed to MLT, such as improved quality of sleep, normalization of disturbances resulting from the difference in time zones (jet lag), reduction of the risk of heart disease, and protection against cancer and aging, although these findings have not been unequivocally confirmed (Reiter \& Robinson, 1996). The pineal gland also influences the endocrine/reproductive systems (function of the gonads, thyroid and adrenals) and the immune system (leukocyte activity) (Wilkinson, 1991; Caroleo et al., 1992).

The involvement of the pineal gland in the homeostasis of glucose and insulin levels in blood has been suggested in several investigations over the last decades. A peptide extracted from the bovine pineal gland has been demonstrated to have insulin-like effects (Milcu et al., 1963). Other authors have reported that aliquots of a medium used for pineal gland incubation stimulates insulin release from "in vitro" pancreatic islets (PI) (Gorray et al., 1979). These data suggest that MLT can exert an influence on the secretion and/or action of insulin; however, studies on pinealectomised animals have demonstrated contradictory results, such as reduction of blood glucose (Csaba \& Barath, 1971) and hyperinsulinemia (Milcu et al., 1971; Gorray et al., 1979), or low basal insulin levels and hyperinsulinemia under certain photoperiod and feeding conditions in pinealectomised animals (Gorray \& Quay, 1978).

Studies have demonstrated the influence of the pineal gland on plasma glucose levels, such as an increased sensitivity of mouse adipose tissue to insulin when incubated with melatonin (Lima et al., 1994) and an elevation of plasma glucose and an insufficient response of the glycemic curve to the oral glucose tolerance test (GTT) in pinealectomised rats, indicating peripheral resistance to insulin (Reis et al., 1996). There is evidence that melatonin reduction can be involved in the genesis of diabetes mellitus type 2 since diabetics may present abnormally low levels of this hormone (Reiter \& Robinson, 1996). Besides, MLT reduces hyperglycemia and protein glycosylation, as demonstrated by Montilla et al. (1998).

In view of the large number of reports that associate the activity of the pineal gland with the endocrine function of the pancreas, we carried out the present study to verify the influence of the pineal gland on the morphology, morphometry and physiology of pancreatic islets, and especially on the secretion and action of insulin.

\section{MATERIAL AND METHODS}

\section{Experimental groups}

Male Wistar rats (Rattus norvegicus) weighing 200 to $300 \mathrm{~g}$ were divided into five groups of ten animals each, i.e., two control groups: NC (normal controls), NS (sham operated) and three experimental groups: Px (25) (pinealectomised evaluated 15-25 days after surgery), Px (70) (pinealectomised evaluated 60-70 days after surgery), and ALX (injection of alloxan monohydrate).

\section{Surgery (normal control and sham-operated animals)}

The animals were weighed, anesthetized with sodium pentobarbital (Nembutal, Abbot, $40 \mathrm{mg} /$ $\mathrm{kg} / \mathrm{ip}$ ) and placed in a stereotaxic apparatus for immobilization of the head. A small incision was made in the skin, exposing the area of the lambda in the skull (parieto-occipital suture), and craniotomy was performed with a circular drill. After removal of the bone fragment and retraction of the sagittal sinus the pineal gland was completely removed by its stem. The bone fragment was returned to its place and the surgical planes were sutured (Waynforth \& Flecknell, 1992). The animals recei- 
ved a prophylactic antibiotic injection (pentabiotic, Fontoura Wyeth, $0.4 \mathrm{ml} / \mathrm{animal} / \mathrm{im}$ ).

Sham surgery was performed following the same procedure as described above, except that the pineal gland was not removed.

\section{Alloxan injection (diabetic group)}

The animals were fasted for 36 hours, with free access to water, and then received alloxan monohydrate $(40 \mathrm{mg} / \mathrm{kg} / \mathrm{iv}$ of a $2 \%$ solution Nutritional Biochemical Corp) diluted with physiologic saline. The alloxan injection was made through the external jugular vein in animals previously anesthetized by ethyl ether inhalation. Approximately 30 min after alloxan administration, food was offered to the animal.

\section{Animal management}

Before and after being submitted to the respective scheduled procedures, the animals were kept into metabolic cages at room temperature $\left(25^{\circ} \mathrm{C}\right)$ on a 12 hour light- 12 hour dark cycle. Water and food ingestion and diuresis were recorded daily. At the end of the observation period the animals were weighed and sacrificed by excess ethyl ether inhalation for blood collection and pancreas removal.

\section{Blood an pancreas collection}

Under deep ether anesthesia, we opened the chest of the animals and punctured the left ventricle using a syringe containing sodium heparin as an anticoagulant (Eurofarma), for collection of 3 to $5 \mathrm{ml}$ of blood ( $9 \mathrm{am}-3 \mathrm{pm})$. The animal was then perfused, first with saline solution $(0.9 \% \mathrm{NaCl})$ until the organs had blanched, and then with $10 \%$ formalin, $\mathrm{pH}$ 7.4. After perfusion, the pancreas was removed and weighed.

\section{Biochemical analysis}

Plasma obtained from collected blood was used for glucose $(\mathrm{md} / \mathrm{dl})$, total protein $(\mathrm{g} / \mathrm{dl})$, triglyceride (mg/dl), cholesterol (mg/dl) and insulin (IU/ $\mathrm{mg}$ ) determinations according to standard procedures.

\section{Histological processing of the pancreas}

The collected pancreas was divided into three segments (proximal, middle and distal) in relation to the duodenum and submitted to routine histological processing. The material was embedded in paraffin and $5 \mathrm{~mm}$ sections were obtained and placed on slides. The material was dried in an oven at $37^{\circ} \mathrm{C}$ and stained with hematoxylin-eosin for morphometric and morphological analysis.

\section{Morphometric analysis}

The slides containing pancreatic sections were examined for number of islets, islet area and total section area. The total section area was determined using a magnifying glass (Bbt, Krauss) coupled to a light camera used to project the section onto a paper sheet. The contours were drawn with a pencil and the area was measured using a semiautomatic image analyzer (Mop-Videoplan, Kontron, Elektronic, Munich, Germany) which determined the area of the section on the basis of the perimeter of each image. The results are reported as $\mathrm{cm}^{2}$.

A light microscope with a 10x objective was used to determine islet density by counting the number of islets present in each section. Knowing the area of the section and the number of islets present in it, we calculated islet density, which is reported as number of islets $/ \mathrm{cm}^{2}$.

Islet area was determined using a videocamera coupled to a light microscope with a 10x magnifying objective. The images of the islets were exhibited on a video monitor integrated to a cursor that moved on the surface of a graphic mensuration table.

These were connected to the image interactive analysing system (Mop-Videoplan, Kontron, Elektronic, Munich, Germany) that measured the area of each islet in $\mathrm{mm}^{2}$ by its perimeter.

\section{Morphological analysis}

The slides containing the pancreatic sections were examined under the light microscope for general pathological processes in the endocrine compartment such as the presence and intensity of degeneration, cell death (necrosis or apoptosis), inflammation and disturbances of the circulation (hyperemia, edema, hemorrhage), alterations of the interstitial space and of cell differentiation and growth. These processes, when present, were scored as discrete, moderate and marked in terms of intensity and the number of islets that presented each one of the observed alterations was also recorded. 


\section{Statistical analysis}

All results were grouped, statistically described and later compared to the results obtained from the normal control group. The statistical procedures used were ANOVA and Kruskal-Wallis test followed by Dunn's second order test to identify which group were different to the normal control group. The level of significance was set at $\mathrm{p}<$ 0.05 for all parameters.

\section{RESULTS}

\section{Biochemical analysis}

The plasma glucose values are presented in Fig. 1. The animals of groups Px (25) and Px (70) did not present significant differences in plasma glucose levels when compared to the NC group. The glycemic level of the ALX group was significantly higher when compared to the animals of the NC group $(\mathrm{p}<0.01)$. Blood insulin did not show significant differences in the animals of groups Px (25) and Px (70) compared to the NC group, but the levels of the Px (70) group showed a tendency to increase, while the blood insulin levels of the ALX group were lower than those of the NC group (p<0.01) (Fig. 2).

\section{Morphometric analysis}

Figs. 3 and 4 present the PI area of the pancreatic segments, which was larger for Px (70) animals compared to the NC group $(\mathrm{p}<0.05)$ and show a reduction of islet density in the Px (70) group compared to the Px $(25)$ group $(p<0.05)$.

\section{Morphological analysis}

The Fig. 5 shows that the PI of NC animals were well defined, with well formed cellular cords and contained cells surrounded by scarce connective tissue and some capillary vessels, with a finely granular cytoplasm and with the nucleus containing some vesicles. Cytoplasmic vacuoles were occasionally observed, suggestive of hydropic degeneration or compatible with steatosis.

The Fig. 6 shows the PI of the Px (25) animals, which presented a reduction of cell volume and thin cellular cords with increased interstitial space. Many intracytoplasmic vacuoles were noticed, suggestive of hydropic degeneration and steatosis. The pancreatic islets of Px (70) animal presented morphological characteristics similar to those of the NC group, i.e., well defined limits, a more compact aspect and containing cells with rare intracytoplasmic vacuoles.

ALX animals presented PI with less precise contours, with reduced number of cells and increases interstitial space. There were numerous intracytoplasmic vacuoles, compatible with steatosis and hydropic degeneration (Fig. 7).

The analysis of the general pathological processes (degeneration, cell death - necrosis or apoptosis, inflammation, hyperemia, edema, hemorrhage, alterations of the interstitial space and of cell differentiation and growth) observed in the PI of the pancreatic segments studied demonstrated a greater intensity of degeneration in groups NS, Px (25) and ALX, compared to the NC group ( $\mathrm{p}<$ $0.01)$.

\section{DISCUSSION}

The present results did not show any change in the parameters under study in the sham-operated group, indicating that surgical stress does not produce significant modifications. On the other hand, our results demonstrate that the pineal gland seems to exert an influence on the endocrine pancreas. This statement is based on the fact that, although Px (25) animals evaluated 15-25 days after surgery showed a slight increase in plasma glucose levels associated with a slight reduction of plasma insulin levels, without statistical significance, morphological analysis of the PI of these animals revealed a decreased cell population with thin cell cords and increased interstitial spaces, and numerous intracytoplasmic vacuoles suggestive of degeneration. Possibly the lack of MLT reduced the ability of the pancreas to secrete insulin, although there may also have been a reduction in tissue sensitivity to insulin, as reported by Lima et al. (1994).

The biochemical results obtained with the animals of the Px (70) group evaluated 60-70 days after surgery did not show any significant differences, but only a tendency to the elevation of insulin levels, in agreement with Csaba \& Barath (1971) and Gorray et al. (1979), who reported a discrete elevation of blood insulin level after pinealectomy. 
These animals showed a reduced islet density and a slight increase in PI area suggesting that the tendency to blood glucose elevation due to the

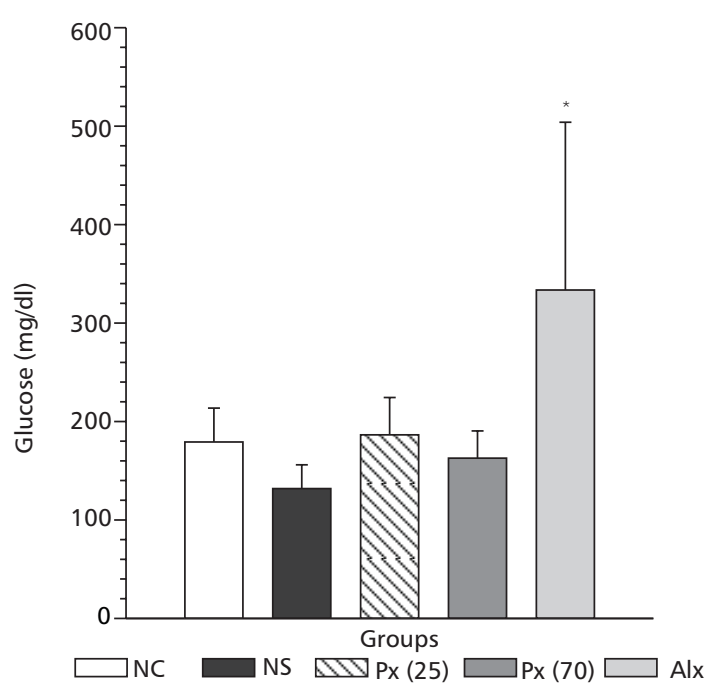

Fig. 1 - Measurement of plasma glucose $(\mathrm{mg} / \mathrm{dl})$ in control rats $(\mathrm{NC}, \mathrm{n}=10, \mathrm{NS}, \mathrm{n}=10)$ and in experimental rats (PX (25), $\mathrm{n}=10, \mathrm{Px}(70), \mathrm{n}=10, \mathrm{Alx}, \mathrm{n}=10)$. Values are reported as means $\pm \mathrm{SD}$. $* \mathrm{p}<0.05$.

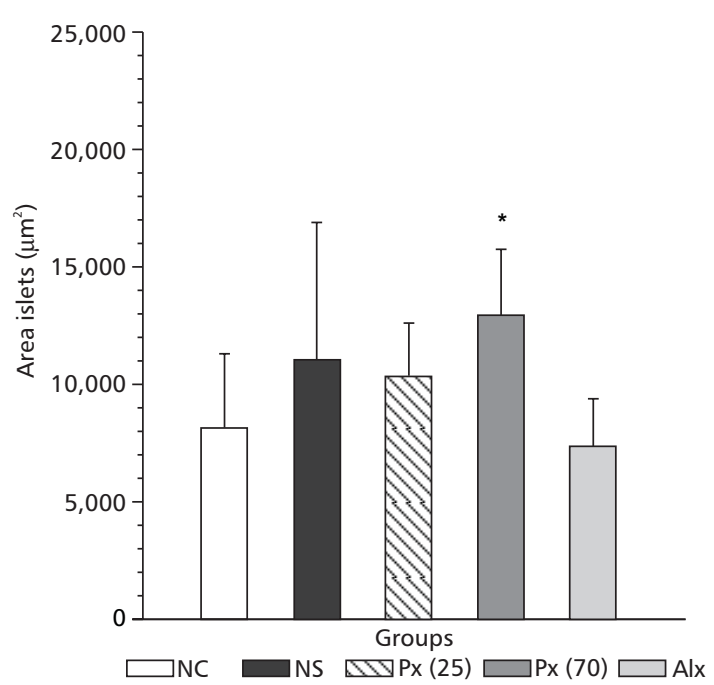

Fig. 3 - Measurement of the total pancreatic islets area $\left(\mu \mathrm{m}^{2}\right)$ in pancreas slices from control rats $(\mathrm{NC}, \mathrm{n}=10 ; \mathrm{NS}, \mathrm{n}=10$ ) and in experimental rats (Px (25), $\mathrm{n}=10$; $\mathrm{Px}(70), \mathrm{n}=10$; $\mathrm{Alx}, \mathrm{n}=10)$. Values are reported as means $\pm \mathrm{SD}$. ${ }^{*} \mathrm{p}<0.05$. insulin resistance generated by the lack of melatonin may have caused PI overactivity and a morphological aspect similar to the PI of the NC group.

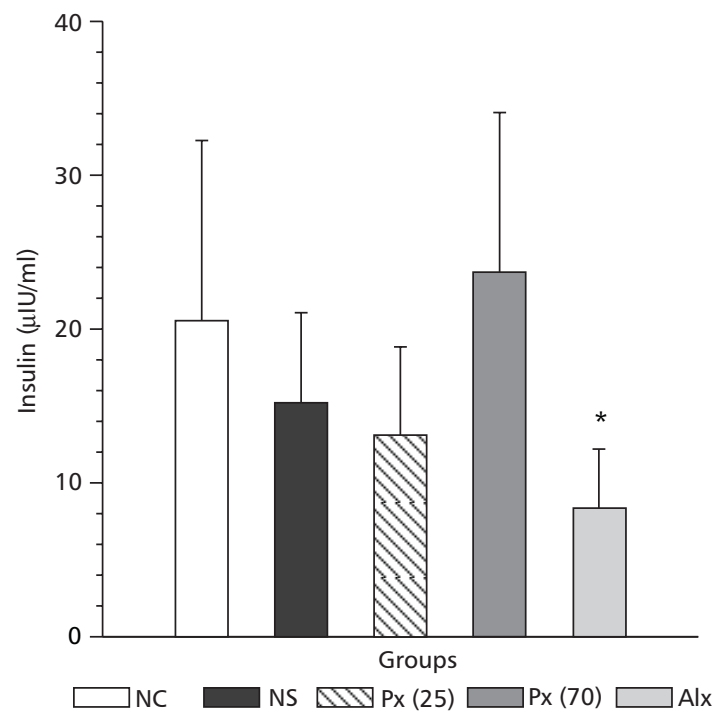

Fig. 2 - Measurement of plasma insulin ( $\mu \mathrm{IU})$ in control rats $(\mathrm{NC}, \mathrm{n}=10 ; \mathrm{NS}, \mathrm{n}=10)$, and in experimental rats ( $\mathrm{Px}$ (25); $\mathrm{n}=10 ; \mathrm{Px}(70), \mathrm{n}=10 ; \mathrm{Alx}, \mathrm{n}=10)$. Values are reported as means \pm SD. $* \mathrm{p}<0.05$.

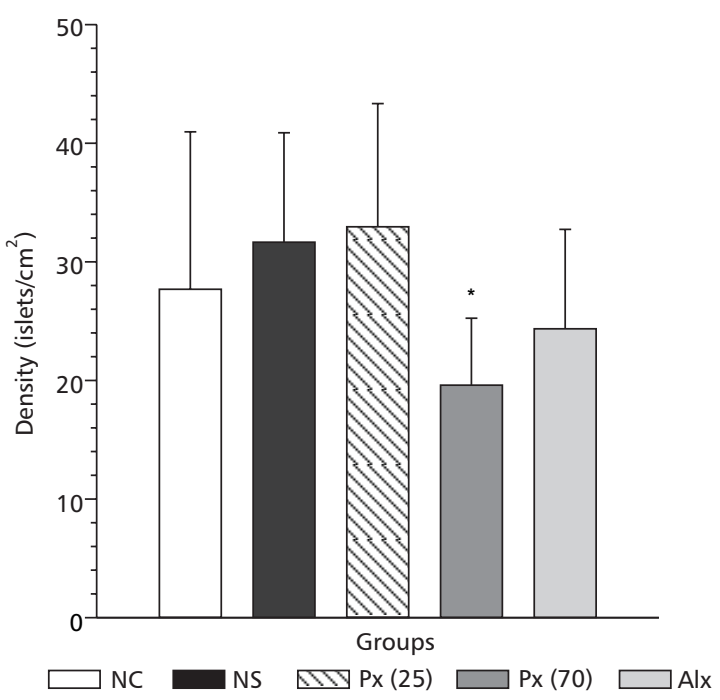

Fig. 4 - Islets density in pancreas slices from control rats $(\mathrm{NC}, \mathrm{n}=10 ; \mathrm{NS}, \mathrm{n}=10)$ and in experimental rats (Px $(25)$, $\mathrm{n}=10 ; \mathrm{Px}(70), \mathrm{n}=10 ; \mathrm{Alx}, \mathrm{n}=10)$. Values are reported as means $\pm \mathrm{SD}$. $* \mathrm{p}<0.05$. 


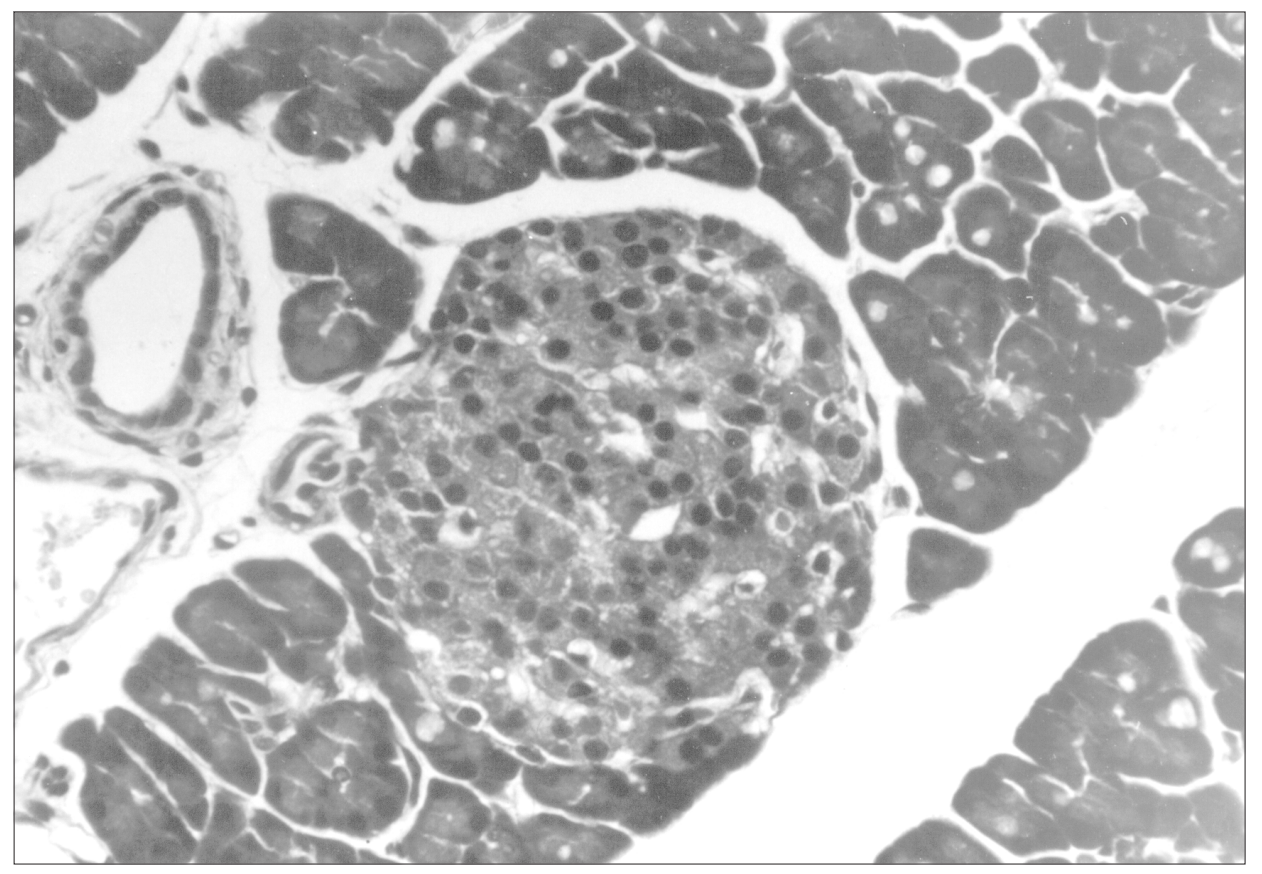

Fig. 5 - Micrography of a segment of pancreas from a NC animal (HE, 500x).

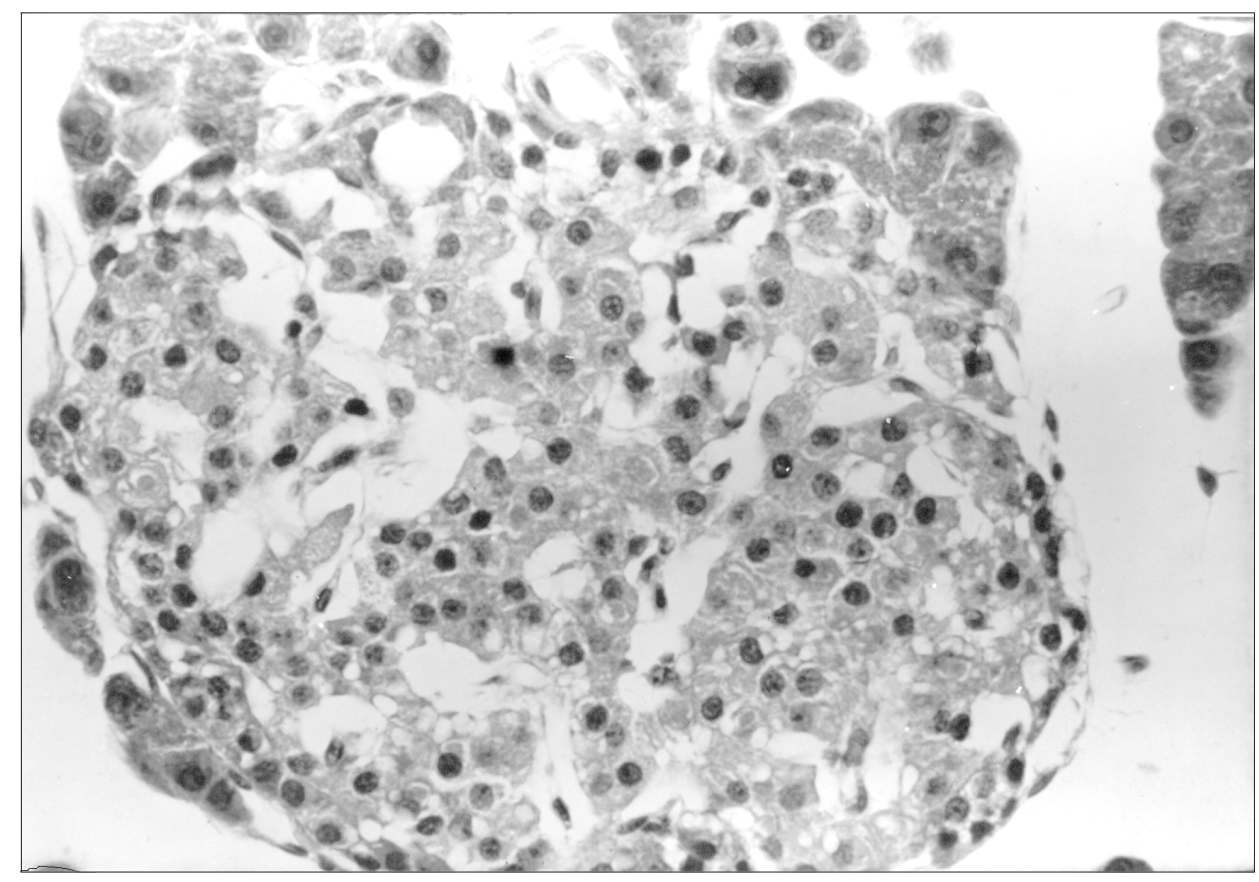

Fig. 6 - Micrography of a pancreatic islet form a Px (25) group rats, thats exhibits a great amount of intracytoplasmatic vacuoles and reduced number of cells (HE, 500x). 
Several studies have suggested an association between MLT and blood glucose control. Reis et al. (1996) suggested that pinealectomised animals present signs similar to those of human type 2 Diabetes Mellitus, with increased blood glucose, normal or decreased insulin levels and higher weight. O'Brien et al. (1986) compared nocturnal levels of MLT in diabetic patients and healthy volunteers and observed that the diabetic patients were producing significantly smaller amounts of MLT.

In our study we used alloxan-treated animals as a positive control experimental group because alloxan is known to have a selective effect on pancreatic beta cells (Rerup, 1970; Bowman \& Rand, 1984). The animals of this group presented Diabetes Mellitus Type 1, with reduction of body and pancreas weight, and increased blood glucose levels and decrease blood insulin levels. Morphological study of the pancreas demonstrated reduction of the number, area and density of PI and a discrete inflammatory infiltrate.

The pineal gland also modifies the activity of other endocrine organs such as the adrenals (Diaz \& Blazquez, 1986), and the influence of MLT on beta cells activity may be indirect since cortisol and epinephrine are known to influence both insulin secretion and blood glucose (Goodman, 1994).

Analysis of literature data together with the present data which showed morphological modifications in the PI of pinealectomised rats does not permit to propose a hypothesis that fully explains the mechanisms by which MLT acts.

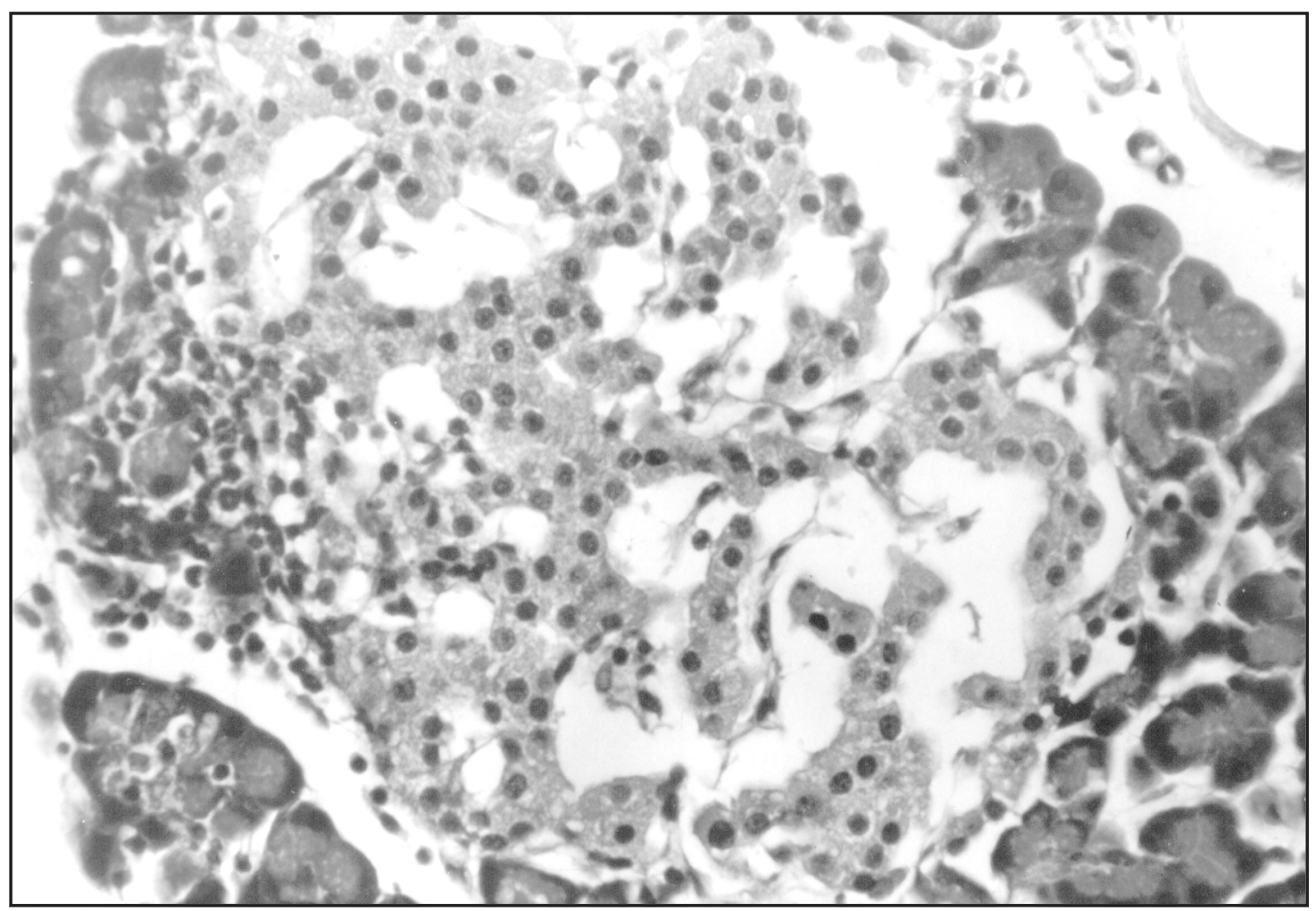

Fig. 7 - Pancreatic islet from an Alx group rat, that exhibits a strong reduction in the number of cells and focal inflammatory infiltration (HE, 400x). 


\section{REFERENCES}

BOWMAN, W. C. \& RAND, M. J., 1984, Farmacologia. Bases bioquímicas y patológicas. Aplicaciones clínicas. $2^{\text {nd }}$ ed. Cap.19: Sistema endocrina y drogas que afectan su función. Nueva Editorial Interamericana, México, pp.3840, 43p.

CAROLEO, M. C., FRASCA, D., NISTICO, G. \& DORIA, G., 1992, Melatonin as immunomodulator in immunodeficient mice. Immunopharmacology, 23: 81-89.

CSABA, G. \& BARATH, P., 1971, Are Langerhans' islets influenced by the pineal body? Experientia, 27: 962.

DIAZ, B. \& BLAZQUEZ, E., 1986, Effect of pinealectomy on plasma glucose, insulin and glucagon levels in the rat. Horm. Metab. Res., 18(4): 225-229.

GOODMAN, H. M., 1994, Basic-medical endocrinology. $2^{\text {nd }}$ ed. Cap.9: Hormonal regulation of fuel metabolism. Raven Press, New York, pp.203-224.

GORRAY, K. C. \& QUAY, W. B., 1978, Effects of pinealectomy and of sham-pinealectomy on blood glucose levels in the alloxan-diabetic rat. Horm. Metab. Res., 10(5): 389-392.

GORRAY, K. C., QUAY, W. B. \& EWART, R. B., 1979, Effects of pinealectomy and pineal incubation medium and sonicates on insulin release by isolated pancreatic islets in vitro. Horm. Metab. Res., Stuttgart, 11(7): 432-36.

LIMA, F. B., MATSUSHITA, D. H., HELL, N. S. DOLNIKOFF, M. S., OKAMOTO, M. M. \& CIPOLA NETO, J., 1994, The regulation of insulin action in isolated adipocytes. Role of the peridicity of food intake, time of day and melatonin. Braz. J. Med. Biol. Res., São Paulo, 27(4): 995-1000.

MILCU, S. M., MILCU, I. \& NANU, L., 1963, La role de la glande penéale dans le metabolisme des glucides. Ann. Endocrinol., 24: 233-254.
MILCU, S. M., NANU-IONESCO, L. \& MILCU, I., 1971, The effect of pinealectomy on plasma insulin in rats. In: G. E. W. Wolstenholme \& J. Night, Pineal gland. Churchill-Livingstone, Edinburgh, pp. 345-357.

MONTILLA, P. L., VARGAS, J. F., TÚNEZ, I. F., MUÑOZ, M. C., VALDEVIRA, M. E. \& CABRERA, E. S., 1998, Oxidative stress in diabetic rats induced by streptozotocin: protective effects of melatonin. J. Pineal Res., 5: $94-100$.

O'BRIEN, I. A. D., LEWIN, I. G., O'HARE, J. P., ARENDT, J. \& CORRAL, R. J. M., 1986, Abnormal circadian rhythm of melatonin in diabetic autonomic neuropathy. Clinical Endocrinol., 24(4): 359-364.

REIS, L. C., SOUSA, J. C., BORGES, L. S., SPADARO, F., SANTOS, B. M. \& COLLUS, L. O., 1996, Metabolic changes and plasmatic biochemistry after pinealectomy in rats. Rev. Méd. Minas Gerais, 6(3): 101-103.

REITER, R. J., 1986, The pineal gland: an important link to the enviroment. News Physiol. Sci., 1: 202-205.

REITER, R. J. \& ROBINSON, J., 1996, Melatonin: your body's natural wonder drug. Bantan Books, 289p.

RERUP, C. C., 1970, Drugs producing diabetes through damage of the insulin secreting cells. Pharm. Rev., 22: 485-518.

WAYNFORTH, H. B. \& FLECKNELL, P. A., 1992, Experimental and surgical technique in the Rat. $2^{\text {nd }}$ ed. Cap. 5: Specific surgical operations. Academic Press, San Diego, pp. 279-284.

WILKINSON, C. W., 1991, Endocrine rhythms ans pineal gland. In: T. Ruch \& H. D. Patton, Physiology. Saunders Co., Philadelphia, EUA, pp. 1239-1261. 